Research Article

\title{
A Study on Dynamics of Major Cereal Crop Production in Nepal
}

\author{
Niroj Dahal ${ }^{1}$, Sarthak Ghimire ${ }^{1 *}$, Rakshya Poudel ${ }^{2}$ \\ ${ }^{1}$ Agriculture Economist, Ministry of Land Management, Agriculture and Cooperatives, Biratnagar, Nepal. \\ ${ }^{2}$ Agriculture Economist, Directorate of Livestock and Fisheries Development, Biratnagar, Nepal. \\ *Corresponding author email: sarthakghimire17@gmail.com
}

\section{Article Information}

Received: 31 December 2021

Revised version received: 19 January 2022

Accepted: 21 January 2022

Published: 28 January 2022

\section{Cite this article as:}

N. Dahal et al. (2022) Int. J. Soc. Sc. Manage. 9(1):

13-18. DOI: $\underline{10.3126 / i j s s m . v 9 i 1.42716}$

*Corresponding author

Sarthak Ghimire,

Agriculture Economist, Ministry of Land Management, Agriculture and Cooperatives, Biratnagar, Nepal.

Email: sarthakghimire17@gmail.com

Peer reviewed under authority of IJSSM

(C)2022 IJSSM, Permits unrestricted use under the CC-By-NC license.

\section{OPEN OACCESS}

This is an open access article $\&$ it is licensed under a Creative Commons Attribution Non-Commercial 4.0 International

(https://creativecommons.org/licenses/by-nc/4.0/)

Keywords: Nepal; Food and Nutrition Security; Cereal crops; Growth trend; Instability analysis; Decomposition analysis
\end{abstract}

\section{Introduction}

Nepalese economy is heavily dependent on the agriculture sector, which contributes about 26 percent of the total GDP and 60.4 percent of Nepalese population are involved in agricultural sector (MOF, 2021; NPC, 2019). High degree of variation in altitudinal, topographical and temporal aspects of Nepal has made Nepal rich in agricultural biodiversity. Nepal has high crop species, animal and vegetation diversity. Although Constitution of Nepal, promulgated in 2015 enshrines food as a fundamental right of the Nepalese citizens, but 2.8 million of the them are food insecure (WFP, 2021). In 2019 Nepal ranked $73^{\text {rd }}$ out of 117 countries on Global Hunger Index (NPC, 2019). Nepalese agriculture had gained interest of government and policy makers from earlier plans, but results are not as expected. 
After the failure of the Agriculture Perspective Plan 19952015, government of Nepal has brought Agriculture Development Strategy (ADS) 2015-2035, which is supposed to transform the Nepalese agriculture from subsistence to commercialization, but its implementation is still questionable.

Cereal crops, not only occupy the maximum share in terms of area and production, but also have gained maximum interest of stakeholders related to agriculture. Paddy, wheat, maize, barely, buckwheat and millet are the cereal crops that are grown in Nepal, among which first three occupies 91.31 and 96.67 percent of total area and production of cereal, respectively (MoALD, 2021). Cereal crop plays major role in food and nutrition security in Nepal as Nepalese food habits is based on the cereal crops. Cereal supplies 65 and 60 percent of the total food energy and proteins to the Nepalese population (Regmi, 2016). Cereal crop shares about 33 and 23 percent of the total food expenditure of the rural and urban households, respectively in Nepal.

Paddy, maize and wheat are important crops for food security in Nepal. They occupy first, second and third position, respectively. Paddy and wheat are grown in valley, tars, Terai and irrigated lands in mountain; while maize is mid-hills of the country. Despite having the importance, Nepal is not able to become self-sufficient in terms of cereal crop production. Cereal import dependency ratio is increasing every year and food import to export ratio is all time high. Import of food as increased fourfold from 2011 to 2018 making country vulnerable to food insecurity (NPC, 2019).

Cereal crop production is heavily input intensive in nature. They require large amount of investment in terms of fertilizer, irrigation, labor-force and plant protection chemicals. Only 54 percent of the total cultivated land is irrigated, among which only 33 percent of land has over the year irrigation facilities. Such a situation makes Nepalese cereal production system highly monsoon dependent. Paddy production heavily depends upon the timing and amount of the monsoon rainfall, whereas maize and wheat depends on rainfall on other months. Production of these crops varies due to highly variable, unpredictable rainfall as well as lack of other irrigation system. Similarly, 78 percent of the population hold land size lesser than 0.8 hectare (CBS, 2011). Although the latest data is not available, this situation is much aggravated at the present time due to the unwanted urbanization and housing in the fertile agricultural land. This has pressure on agricultural land to supply food for growing population. Also, chemical fertilizer used in Nepalese cereal production is very low, as Nepal is not able to supply required chemical fertilizer at the production time as Nepal is dependent on India for supply of those fertilizers.
Government has been investing in cereal production since 1960s and there is a slow and steady growth in area, production and yield. In this scenario, there is dearth of research studies which provides overview of the growth and instability of the cereal crops, and it is also necessary to identify the causes of the growth in production. In such background, this paper tries to address the fore mentioned issue by measuring the growth rate and instability in area, production and yield of paddy, wheat and maize in Nepal for 30 years ranging from 1990/91 to 2019/20. Similarly, it also attempts to identify the cause of growth crops by using decomposition method. The result of this study will be helpful for researchers and policy makers to understand the growth of the three major cereal crops of Nepal namely, paddy, maize and wheat; and suggesting suitable policy option to obtain targeted growth. This study is undertaken with following objectives:

* To analyze the trend of major cereal crops Nepal over the study period.

* To examine the extent of instability in area, production and yield of major cereal crops Nepal.

* To study the relative contribution of the area and yield in the production of major cereal crops Nepal.

\section{Research Methodology}

This study is based on the secondary data related to the area, production and yield of the paddy, wheat and maize. Time series data of 30 years on those variables for the period 1990/91 - 2019/20 were collected from various volumes of 'Statistical Information on Nepalese Agriculture', which is published by Agri - Statistics Section, Monitoring, Evaluation and Statistics Division of Ministry of Agriculture and Livestock Development, Kathmandu. Other related data were collected from relevant published by Ministry of Agriculture and Livestock Development, Department of agriculture and other sources. Study period was divided into three sub periods of 10 years viz. period I (1990/91-1999/00), period II (1999/00 - 2009/10) and period III (2010/11-2019/20).

\section{Compound Growth Rate (g)}

Exponential growth function was used to calculate the compound growth rate of area, production and yield of the crops over study period. Function can be written as $\mathrm{Y}_{\mathrm{t}}=$ $\mathrm{ab}_{\mathrm{t}} \mathrm{u}_{\mathrm{t}}$; where $\mathrm{Y}_{\mathrm{t}}=$ variable of which growth rate was calculated, $a=$ intercept, $b_{t}=$ regression coefficient, such that $b_{t}=1+g$; and ut $=$ error term for year $t$. For calculating the growth rate, the above equation was transformed into loglinear form and ordinary least square method (OLS) was used for estimation. Compound growth rate was worked out as $g=($ antilog of $(\ln b)-1) \times 100$. 


\section{Measurement of Instability}

Instability was measured by using coefficient of variation method as used by Gairhe et al. (2018) and Patil \& Yeledhalli (2016). It is worked out as follows:

$\mathrm{CV}=\frac{\sigma}{\mu} \times 100$

where, $\mathrm{CV}=$ Co-efficient of variation, $\sigma=$ Standard deviation of the variable; and $\mu=$ Mean of the variable.

\section{Decomposition Analysis}

Decomposition analysis is used to find the effect of area, yield and interactions between them in increasing the production. It is worked out as:

Area effect $=\left[\left(\mathrm{A}_{0} \Delta \mathrm{Y}\right) \times 100 / \Delta \mathrm{P}\right] ;$

Yield effect $=\left[\left(\mathrm{Y}_{0} \Delta \mathrm{A} \times 100\right) / \Delta \mathrm{P}\right]$ and

Interaction effect $=[(\Delta \mathrm{A} \Delta \mathrm{Y} \times 100) / \Delta \mathrm{P}]$

Where, $\Delta \mathrm{P}=$ Change in production; $\mathrm{A}_{0}=$ Area in base year; $\mathrm{An}=$ Area in current year $; \mathrm{Y}_{0}=$ Yield in base year $; \mathrm{Yn}=$ Yield in current year $; \Delta \mathrm{A}=$ Change in area $\left(\mathrm{An}-\mathrm{A}_{0}\right) ; \Delta \mathrm{Y}$ $=$ Change in yield $\left(\mathrm{Yn}-\mathrm{Y}_{0}\right)$.

\section{Result and Discussion}

\section{Trend of Major Cereals in Nepal}

Trend of the area, production and yield of paddy, maize and wheat from 1990/91 to 2019/20 has been shown in Fig. 1-3. The trend line depicts that there is very minor growth in the area of all the crops. Similarly, in term of production and yield, there is observable amount of growth in all the crops. Recently, considerable amount of farmers has shifted from cereal crop cultivation (especially paddy) to other higher value crops like vegetable and fruits, there is no considerable increase in cultivation area in major cereal crops. Similarly, as majority of the arable lands lack irrigation facility, crop production is dependent on rain, frequency and timing of the monsoon have impact on the crop production. Although paddy, maize and wheat are the most invested crops in Nepalese agriculture system, Nepal is not able to minimize the import of the paddy from abroad (Joshi \& Upadhaya, 2020). In case of paddy, this may be also due to the fact that most of the paddy grown is Nepal is short grain medium sized, but with the increase in the purchasing capacity of the urban and semi urban populace, they have changed their preference to long grain and aromatic paddy, making country highly dependent on foreign country, mainly India, to fulfil the market demand (Anynomous, 2018; Parsain, 2021).

\section{Compound Growth Rate (g)}

Growth of the cereal crops over the period was divided into three sub periods and compound growth rate was calculated, which is shown in Table 1 . In paddy crop, it is found that there was significant growth in area of paddy only in period II; and in production and yield in period II. Also, considering whole study area, it is found that there is significant positive growth in production ( 1.48 percent) and yield (1.75 percent) in paddy. Although a minor growth is observed in area (0.09 percent), but it is not statistically significant. In wheat and maize, it is found that there is statistically significant increase in the area, production and yield in all the sub periods and over all time period, except for area in wheat in period III. It is found that there was statistically significant decline in the area of wheat (1.07 percent) in period III. From the compound growth rate analysis, it is found that maximum growth was present in production and yield of wheat, followed by maize and paddy.

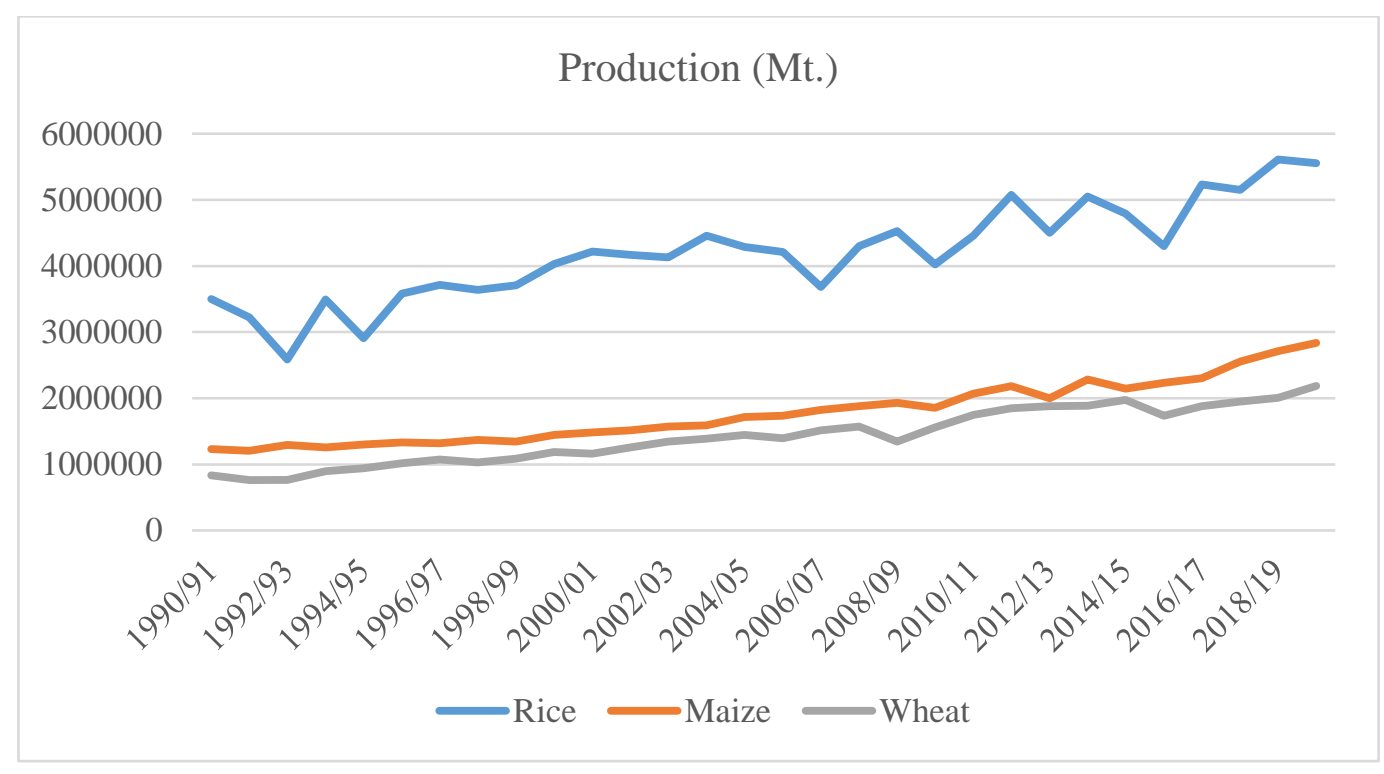

Fig. 1: Area of major cereals from 1990/91 - 2019/20 (Source: MoALD,2021) 


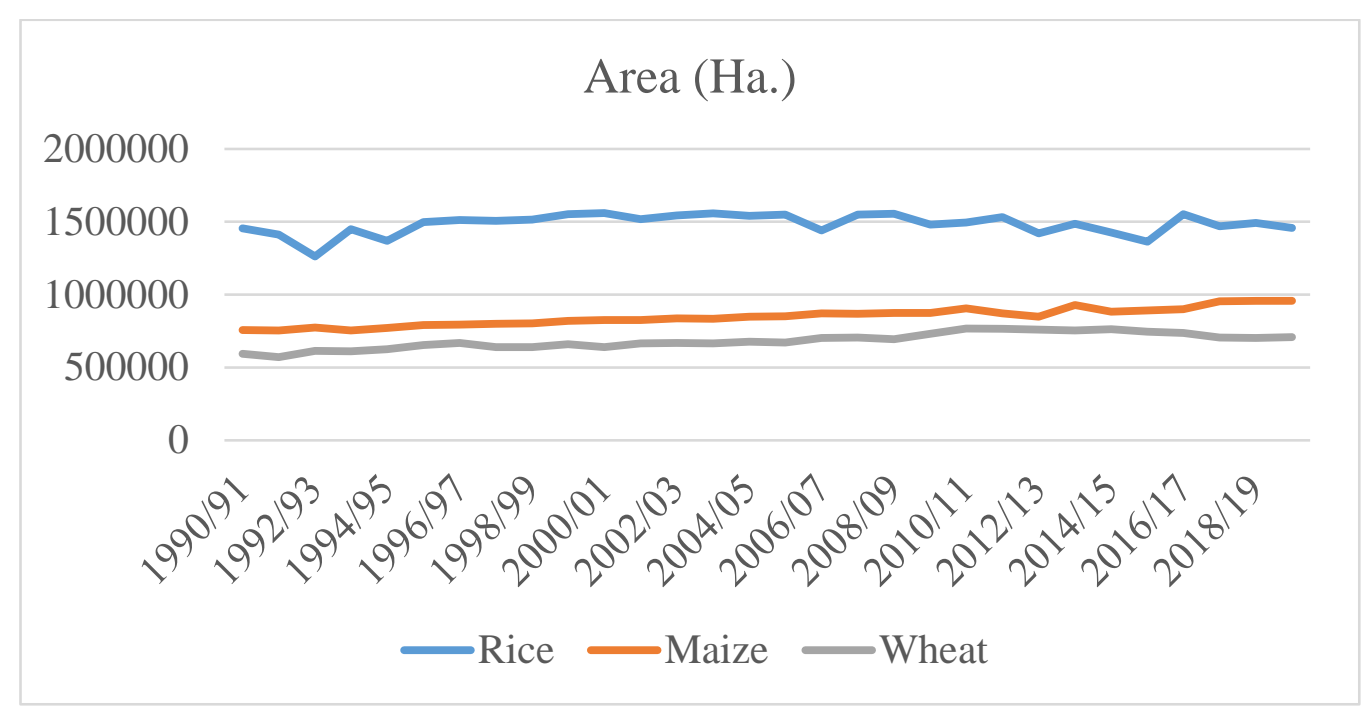

Fig. 2: Production of major cereals from 1990/91 - 2019/20 (Source: MoALD,2021)

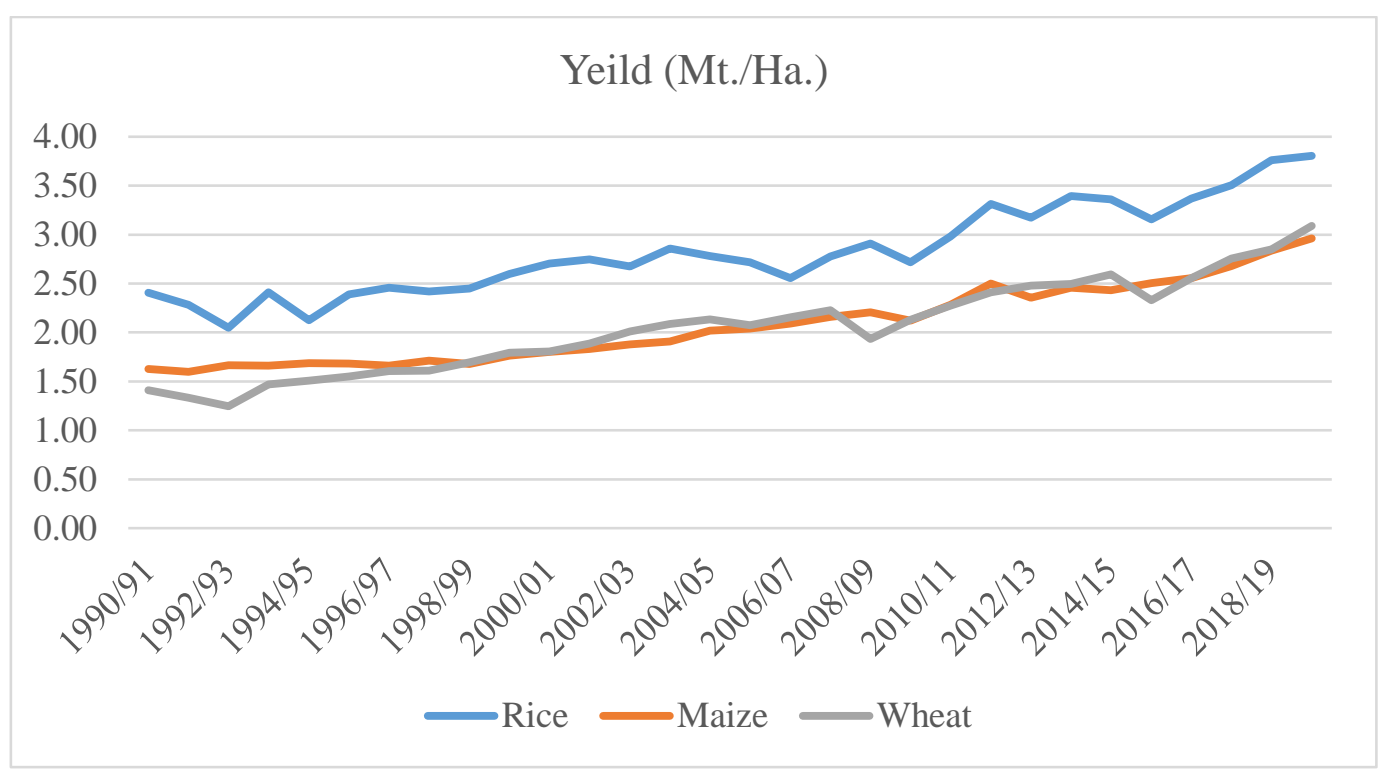

Fig. 3: Yield of major cereals from 1990/91 - 2019/20 (Source: MoALD,2021)

Table 1: Compound growth rate for area, production and yield of the paddy, maize and wheat over 1990/91 2019/20.

\begin{tabular}{|l|l|l|l|l|l|}
\hline Crops & Year & $\begin{array}{l}\text { Period I (1990/91 } \\
-1999 / 00)\end{array}$ & $\begin{array}{l}\text { Period II } \\
(2000 / 2001- \\
2009 / 10)\end{array}$ & $\begin{array}{l}\text { Period III } \\
(2010 / 11- \\
20119 / 20)\end{array}$ & $\begin{array}{l}\text { Over all period } \\
(1990 / 91-2018 / 19)\end{array}$ \\
\hline \multirow{5}{*}{ Paddy } & Area & $1.32^{* *}$ & -0.31 & -0.1 & 0.09 \\
\cline { 2 - 6 } & Production & 2.67 & -0.14 & $2.05^{* *}$ & $1.84^{*}$ \\
\cline { 2 - 6 } & Yield & 1.33 & 0.17 & $2.15^{*}$ & $1.75^{*}$ \\
\hline \multirow{3}{*}{ Maize } & Area & $0.89^{*}$ & $0.78^{*}$ & $1.00^{* *}$ & $0.77^{*}$ \\
\cline { 2 - 6 } & Production & $1.64^{*}$ & $3.10^{*}$ & $3.49^{*}$ & $2.88^{*}$ \\
\cline { 2 - 6 } & Yield & $0.74^{*}$ & $2.31^{*}$ & $2.47^{*}$ & $2.10^{*}$ \\
\hline \multirow{3}{*}{ Wheat } & Area & $1.40^{*}$ & $1.16^{*}$ & $-1.07^{*}$ & $0.80^{*}$ \\
\cline { 2 - 6 } & Production & $4.78^{*}$ & $2.54^{*}$ & $1.61^{* *}$ & $3.48^{*}$ \\
\cline { 2 - 6 } & Yield & $3.34^{*}$ & 1.36 & $2.71^{*}$ & $2.66^{*}$ \\
\hline
\end{tabular}

* Significant at $1 \%$ level of significance

* Significant at $5 \%$ level of significance

(Source: MoALD,2021) 


\section{Measurement of Instability}

Coefficient of variation of the area, production and yield of paddy, maize and wheat from 1990/91 to 2019/20 is shown in Table 2. It is found that in all the crops studied, greater extent of instability was observed in production, followed by the yield. Low degree of instability is present in area as there is minor changes in the area as compared to other variable. This is because there is limited scope of increasing area over the time; and also in decreasing area because crop studied are staple food crops (Gairhe et al., 2018) .

\section{Decomposition Analysis}

Decomposition analysis of the production of the paddy, maize and wheat over the study period is presented in the Table 3. It found that area effect is high in period I, III and over all period in paddy than yield effect and interaction effect; showing that increasing in area is the major source of growth of paddy production as compared to growth in yield and interaction effect. In period II, there is negative area effect (-11.05 percent), which is offset by yield effect (110.49 percent). In case of maize and maize, in all the time periods and over all study time frame, area effect is higher than yield and interaction effect. In the period III, yield effect and interaction effect is found to be negative.

Table 2: Coefficient of variation of area, production and yield of the paddy, maize and wheat over 1990/91 2019/20.

\begin{tabular}{|c|c|c|c|c|c|}
\hline Crops & Year & $\begin{array}{l}\text { Period I } \\
(1990 / 91 \text { - } \\
1999 / 00)\end{array}$ & $\begin{array}{l}\text { Period II } \\
(2000 / 2001- \\
2009 / 10)\end{array}$ & $\begin{array}{l}\text { Period III } \\
(2010 / 11- \\
20119 / 20)\end{array}$ & $\begin{array}{l}\text { Over all period } \\
(1990 / 91-2018 / 19)\end{array}$ \\
\hline \multirow[t]{3}{*}{ Paddy } & Area & 5.47 & 2.24 & 3.60 & 4.64 \\
\hline & Production & 10.98 & 5.28 & 9.63 & 17.21 \\
\hline & Yield & 6.03 & 3.73 & 8.34 & 16.16 \\
\hline \multirow[t]{3}{*}{ Maize } & Area & 2.75 & 2.28 & 3.97 & 6.93 \\
\hline & Production & 5.09 & 8.99 & 11.37 & 25.68 \\
\hline & Yield & 2.58 & 6.78 & 7.88 & 18.82 \\
\hline \multirow[t]{3}{*}{ Wheat } & Area & 4.64 & 3.62 & 3.30 & 7.78 \\
\hline & Production & 14.11 & 8.89 & 6.51 & 28.75 \\
\hline & Yield & 10.31 & 6.16 & 9.21 & 22.87 \\
\hline
\end{tabular}

(Source: MoALD,2021)

Table 3: Decomposition analysis of production of the paddy, maize and wheat over 1990/91 - 2019/20.

\begin{tabular}{|l|l|l|l|l|l|}
\hline Crops & Year & $\begin{array}{l}\text { Period I } \\
\mathbf{( 1 9 9 0 / 9 1 -} \\
\mathbf{1 9 9 9 / 0 0 )}\end{array}$ & $\begin{array}{l}\text { Period II } \\
\mathbf{( 2 0 0 0 / 2 0 0 1 -} \\
\mathbf{2 0 0 9 / 1 0})\end{array}$ & $\begin{array}{l}\text { Period III } \\
\mathbf{( 2 0 1 0 / 1 1 -} \\
\mathbf{2 0 1 9 / 2 0})\end{array}$ & $\begin{array}{l}\text { Over all period } \\
\mathbf{( 1 9 9 0 / 9 1 - 2 0 1 9 / 2 0})\end{array}$ \\
\hline Paddy & Area Effect & 52.84 & -11.05 & 113.10 & 99.30 \\
\cline { 2 - 6 } & Yield Effect & 43.68 & 110.49 & -10.27 & 0.44 \\
\cline { 2 - 6 } & Interaction effect & 3.48 & 0.56 & -2.84 & 0.26 \\
\hline Maize & Area Effect & 49.56 & 70.80 & 80.19 & 63.11 \\
\cline { 2 - 6 } & Yield Effect & 46.43 & 24.80 & 15.26 & 20.24 \\
\cline { 2 - 6 } & Interaction effect & 4.01 & 4.39 & 4.55 & 16.65 \\
\hline \multirow{3}{*}{ Wheat } & Area Effect & 65.28 & 51.89 & -31.05 & 73.73 \\
\cline { 2 - 6 } & Yield Effect & 27.31 & 40.82 & -11.11 & 12.00 \\
\cline { 2 - 6 } & Interaction effect & 7.41 & 7.29 & 14.28 \\
\hline
\end{tabular}




\section{Summary and Conclusion}

This study analyses the dynamics of area, production and yield of the major cereal crops namely, paddy, wheat and maize in Nepal over the period of 1990/91 to 2019/20. It is found that there was significant growth in area of paddy only in period I; and in production and yield in period II and overall time period. In wheat and maize, it is found that there is statistically significant increase in the area, production and yield in all the sub periods and over all time period, except for area in wheat in period III. Similarly, it is found that in all the crops studied, greater extent of instability was observed in production, followed by the yield. And, in all the crops, area effect is higher than yield and interaction effect in all the time periods and whole study time frame. Although the study shows that area has greater impact in production, there is limited scope in area expansion (Gairhe et al., 2018), due to the increasing population, urbanization and forest cover, so in order to increase the production of the cereal crops, policies and programs should be directed toward increasing yield. For increasing the yield of the cereal crops and boost the level of the food security, following measured should be adopted:

- Majority of the cereal production system are subsistence in nature following conventional method of crop production, in this background, government and related authorities should focus on providing training and extension services on commercial packages of practice.

- Majority of the Nepalese cereal growers are growing varieties that fetch low value in the market, providing low income to the farmer. So, market-oriented varieties of the cereals should be promoted, along with development of market infrastructure. Government should also provide marketing infrastructural facility so that cereals growers get remunerative price of their produce.

- Government should fix appropriate minimum support price and regulatory bodies should ensure that farmers fetch at least minimum support price.

- Crop insurance should be promoted and it should be subsidized by the government, as well as legal and documentation process should also be made easier.

- Government should ensure the timely and adequate availability of the chemical fertilizers and other agrochemicals like insecticide, herbicide, etc.

- As majority of the cereal cultivation area are unirrigated or lack year around irrigation, government and related stakeholders should focus on providing adequate irrigation facilities by carrying out special program.

\section{Authors Contribution}

All authors have contributed equally to this paper.

\section{Conflict of Interest}

No conflict of interest with the present work.

\section{References}

Anynomous (2018) Demand for Basmati spikes rice import bill by $21 \mathrm{pc}$ to Rs 17b. The Kathmandu Post. Retrieved from: https://kathmandupost.com/money/2018/03/19/demandfor-basmati-spikes-rice-import-bill-by-21pc-to-rs17b

CBS (2011) Population Census, 2011. Retrived from: https://unstats.un.org/unsd/demographicsocial/census/documents/Nepal/Nepal-Census-2011Vol1.pdf

Gairhe S, Shrestha HK and Timsina K (2018) Dynamics of Major Cereals Productivity in Nepal. Journal of Nepal Agricultural Research Council 4: 60-71. https://doi.org/10.3126/jnarc.v4i1.19691

Joshi KD and UpadhayaS (2020) The rise of rice in Nepal. Nepali Times. Retrieved from: https://www.nepalitimes.com/banner/the-rise-of-rice-innepal/

MoALD (2021) Statistical Information on Nepalese Agriculture 2019/20.

MOF (2021) Economic Survey 2021.

NPC (2019) The food security atlas of Nepal. Retrieved from: https://www.npc.gov.np/images/category/Food_Security_ Atlas_2019.pdf

Parsain S (2021) Nepal's agricultural goods imports soar to Rs325 billion despite Covid disruption. The Kathmandu Post. Retrieved from: https://kathmandupost.com/money/2021/07/28/nepal-sagri-imports-soar-to-rs325-billion-despite-coviddisruption

Patil NA and Yeledhalli RA (2016) Growth and instability in area, production and productivity of different crops in Bengaluru division. International Journal of Agriculture, Environment and Biotechnology, 9(4): 599-611. https://doi.org/10.5958/2230-732X.2016.00078.4

RegmiHR (2016) Food and nutrition security: A status report of Nepal.

WFP (2021) WFP Nepal Country Brief. Retrieved from: https://docs.wfp.org/api/documents/WFP0000131226/download/?_ga=2.237543683.2025134552. $1631414051-637222403.1631414051$ 